\title{
Antioxidant, Anti-quorum Sensing and Cytotoxic Properties of the Endophytic Pseudomonas Aeruginosa CP043328.1 's Extract
}

\author{
L. S. Ngidi ${ }^{1 *}$, C. I. Nxumalo' ${ }^{1}$, J. S. Shandu' ${ }^{1}$, T.S. Maliehe', K. Rene ${ }^{2}$
}

\section{S. Ngidi ${ }^{1, *}$, C. I. Nxumalo', J. S. Shandu' ${ }^{1}$, T.S. Maliehe ${ }^{1}$, K. Rene ${ }^{2}$}

'Department of Biochemistry and Microbiology, Faculty of Science and Agriculture, University of Zululand, Private Bag X1001, KwaDlangezwa 3886, SOUTH AFRICA.

${ }^{2}$ Discipline of Medical Biochemistry, College of Health Sciences, University of KwaZuluNatal, Private Bag X 54001, Durban 4000 , SOUTH AFRICA.

\section{Correspondence}

\section{S. Ngidi}

Department of Biochemistry and

Microbiology, Faculty of Science and

Agriculture, University of Zululand, Private Bag X1001, KwaDlangezwa 3886, SOUTH AFRICA

E-mail: londekangidi@gmail.com

History

- Submission Date: 04-10-2020;

- Review completed: 21-10-2020;

- Accepted Date: 09-11-2020.

DOI : 10.5530/pj.2021.13.43

Article Available online http://www.phcogj.com/v13/i2

\section{Copyright}

(C) 2021 Phcogj.Com. This is an openaccess article distributed under the terms of the Creative Commons Attribution 4.0 International license.

\section{ABSTRACT}

Background: Novel bioactive compounds are in high demand to combat challenges of microbial resistance. In recent years, secondary metabolites from endophytic bacteria have drawn attention from researchers due to their novel structures and significant biological activities. Objective: This study aimed at extracting secondary metabolites from endophytic Pseudomonas aeruginosa CP043328.1 from Anredera cordifolia leaves for their biological activities. Methods: The anti-SMASH was used to predict the biosynthetic gene clusters of $P$. aeruginosa CP043328.1. The bacteria was resuscitated on Nutrient agar. Ethyl acetate was used to extract the secondary metabolites. Chemical composition of the secondary metabolites was evaluated using gas chromatography-mass spectrometry (GC-MS) and 2, 2-diphenyl-1-picrylhydrazyl (DPPH), and 2, 2-azinobis (3-ethylbenzothiazoline-6-sulfonic acid) (ABTS) methods were used to analyze the scavenging activity. Anti-quorum sensing activity was investigated using Chromobacterium violacuem ATCC 12472 as the biological indicator. Cytotoxicity assay was performed using a tetrozolium-based columetric (MTT) assay. Results: The bacterium has 12 gene clusters that encode for secondary metabolites. The extract revealed 15 volatile constituents with diisooctyl phthalate $(50.51 \%)$ and $[1,2,4]$ oxadiazole, 5-benzyl-3 $(10.44 \%)$ being the major compounds. The extract revealed scavenging capabilities with $\mathrm{IC}_{50}$ of 0.625 $\mathrm{mg} / \mathrm{ml}$ for DPPH and $0.15 \mathrm{mg} / \mathrm{ml}$ for ABTS. It displayed anti-quorum sensing activity with $88 \%$ violacein inhibition at $3.31 \mathrm{mg} / \mathrm{ml}$. According to MTT assay, the extract was found to be safe for use up to $2000 \mathrm{\mu g} / \mathrm{mL}$. Conclusion: P. aeruginosa CP043328.1 shows a potential use as a source of pharmacologically important metabolites.

Key words: Pseudomonas aeruginosa CP043328.1, Chemical composition, Antioxidant activity, Anti-quorum sensing activity, Cytotoxicity assay.

\section{INTRODUCTION}

Infectious and metabolic diseases are among the leading causes of death, causing $15.6 \%$ and $16.7 \%$ death in both women and men respectively. ${ }^{1}$ Infectious diseases cause 14 million deaths worldwide annually which has resulted in a high mortality rate of $4.8 \%$. The problem is worsened by the emergence of antibiotic resistance, as well as the occurrence of multiple resistance of pathogens with the potential of global spread. ${ }^{2}$ Antibiotic resistance is mainly conferred by randomly mutated genes in pathogens as a means of defense mechanism. ${ }^{3}$

The quorum sensing (QS) activity of bioactive compounds is as important as the antibiotic property to combat bacterial pathogenicity and antibiotic resistance. Both Gram-negative and Gram-positive bacteria use QS to synchronize gene expression in a population density-dependent manner. In Gramnegative bacteria, $\mathrm{N}$-acyl-L-homoserine lactone (AHL) signal molecules called autoinducers (AIs) mainly mediate QS. Since QS regulates expression of several virulence factors, quorum sensing inhibitors (QSIs) can be used to attenuate bacterial virulence. Moreover, QSIs qualify biofilms to be more susceptible to conventional antibiotics and the host immune system, and thus, lower doses and fewer antibiotic treatments would be needed. ${ }^{4}$
Reactive oxygen species (ROS) are a group of free radicals derived from oxygen. They are produced as a result of cellular metabolism, and excessive accumulation of ROS leads to oxidative stress which plays an important role in the pathogenesis of various diseases like; cardiovascular diseases, inflammatory diseases, atherosclerosis, cancer, and in many pathological progression in the central nervous system. ${ }^{4,5}$ This leads to the search for novel antioxidant compounds from natural sources such as plant and microbial sources which serve as safe therapeutics. $^{6}$

Microorganisms are recognized as producers of bioactive metabolic compounds of industrial and pharmacological significance. ${ }^{4}$ Pseudomonas is a genus of Gram-negative Gammaproteobacteria, belonging to the family Pseudomonadaceae and containing 216 species and 18 subspecies, with the number of species constantly being discovered. ${ }^{7}$ All members of the genus denote a great deal of metabolic diversity and consequently can dominate a wide range of niches. The well-known studied species include Pseudomonas aeruginosa which is ubiquitous in soil and water. Although there are limited reports of this bacterium as an inhabitant of plants, it has been found as an endophyte in some plant species. ${ }^{8,9}$ Endophytic microorganisms are microorganisms 
that inhabit within plant tissues and often occur as symbionts. ${ }^{10}$ The ability of $P$. aeruginosa strains to grow in diverse environments, including plant tissues is facilitated by the capability to assimilate a large number of compounds that are recalcitrant to other bacterial species, thus producing secondary metabolites and biopolymers, making these strains useful in medicine, industries, and environment.

In medicine, $P$. aeruginosa strains produce a variety of compounds with bacteriostatic or bactericide activity, which are vital in the control of multiple drug-resistant (MDR) bacteria. ${ }^{11}$ They produce compounds with antimicrobial properties, which include a group of peptides called pyocins and other heterocyclic compounds. ${ }^{12}$ Apart from the production of antimicrobial compounds, some strains have been reported to synthesize bioactive compounds with antiinflammatory, neuroprotection, antioxidant, antitumor, antidiabetic, and chemo-modulation properties. ${ }^{13,14}$ Although some strains have been isolated from the plants as endophytes, there remain limited studies of endophytic $P$. aeruginosa conducted, leaving this unique niche unexplored. Thus, endophytic $P$. aeruginosa is considered to be a promising source of novel bioactive metabolites of pharmacological importance.

In this context, we focused on the aspects of extraction of secondary metabolites from endophytic $P$. aeruginosa CP043328.1, which was previously isolated from Anredera cordifolia CIX1; a medicinal plant widely recognized for possession of diverse pharmacological activities. The ethyl acetate crude extract from $P$. aeruginosa CP043328.1 was investigated for its chemical composition, anti-quorum sensing, antioxidant and cytotoxic properties.

\section{MATERIALS AND METHODS}

\section{Chemicals and media}

All chemicals and media used were procured from Sigma-Aldrich and Merck (Pty) Ltd. The water used was glass distilled.

\section{Biosynthetic gene clusters}

The analysis of the secondary metabolite gene clusters in P. aeruginosa CP043328.1 was carried out using the anti-SMASH (antibiotics and Secondary Metabolite Analysis Shell) online tool. The species accession number was submitted to anti-SMASH for the identification of gene clusters. The produced data regarding the type of cluster, most similar known cluster, and percentage similarity was noted. ${ }^{15}$

\section{Metabolites extraction}

P. aeruginosa CP043328.1 was previously isolated from Anredera cordifolia leaves which were collected on $2^{\text {nd }}$ July 2019 from the KwaDlangezwa area in the city of Umhlathuze, KwaZulu-Natal, South Africa (28 ${ }^{\circ} 45 \mathrm{I}^{\mathrm{S}} 31^{\circ} 54$ 'E). The voucher specimen for A. cordifolia species, voucher number CIX1, was prepared and deposited in the University of Zululand Herbarium [ZULU], which is available mainly to researchers. The bacterium was resuscitated on nutrient broth and incubated at $28{ }^{\circ} \mathrm{C}$, overnight. The endophyte was adjusted to McFarland standard (1.5 x $10^{6}$ colony-forming unit $\left./ \mathrm{ml}\right)$ and $200 \mu \mathrm{l}$ of bacterial suspension was inoculated into $500 \mathrm{ml}$ of nutrient broth. The bacterial culture was incubated at $28{ }^{\circ} \mathrm{C}$ for five days on a rotating shaker at $130 \mathrm{rpm}$. After incubation, the broth culture was centrifuged at $5000 \mathrm{rpm}$ for 30 minutes to separate the bacterial cells from their metabolites. The supernatant was extracted with an equal volume of ethyl acetate $(500 \mathrm{ml})$ and left overnight. The solvent phase containing the extracted secondary metabolites was separated using a separating funnel and left to air dry to yield the crude metabolites. ${ }^{16}$

\section{Chemical analysis of volatile compounds of the extract}

GC-MS analysis of ethyl acetate extract was carried out on a Trace GC Ultra gas chromatograph-DSQ mass spectrometer (Thermo Electron Corporation, Waltham, MA, USA) fitted with HP-5 MS capillary column $(30 \mathrm{~m} \times 0.25 \mathrm{~mm} \times 0.25 \mu \mathrm{m})$. The GC oven temperature was programmed to $40{ }^{\circ} \mathrm{C}$, for 3 minutes, followed by an increase of $5{ }^{\circ} \mathrm{C}$ per minute to $105^{\circ} \mathrm{C}$ and then increased by $6^{\circ} \mathrm{C}$ per minute until 220 ${ }^{\circ} \mathrm{C}$ was reached and held at $220^{\circ} \mathrm{C}$ for $10 \mathrm{~min}$. The injector temperature was $250^{\circ} \mathrm{C}$, and the flow rate of carrier gas, helium was set at $1.0 \mathrm{ml}$ per minute, with a 10:1 split ratio. The MS operating parameters were as follows: ionization voltage, $70 \mathrm{eV}$, and the ion source temperature was $250{ }^{\circ} \mathrm{C} .{ }^{17}$

\section{Anti-quorum sensing activity of the crude extract}

Quantitative evaluation of quorum sensing inhibitory activity of the extract was carried out based on its ability to inhibit the production of purple pigment violacein produced by Chromobacterium violaceum ATCC 12472 . The strain was cultured aerobically in Luria broth at $30^{\circ} \mathrm{C}$, $130 \mathrm{rpm}$ with the addition of increasing concentrations of the extract. $C$. violaceum ATCC 12472 without the extract served as a negative control. Thereafter, two millilitres of an overnight culture broth was centrifuged at 13,000 rpm for 15 minutes to precipitate the insoluble violacein. The culture supernatant was discarded and the pellet was evenly suspended in $2 \mathrm{ml}$ of dimethyl sulfoxide (DMSO). The solution was centrifuged at 13,000 rpm for 10 minutes to remove the cells and the violacein was quantified by measuring the optical density (OD) at $585 \mathrm{~nm}$ using a UV-Vis spectrophotometer (UV-1800, Shimadzu, Kyoto, Japan). The percentage of violacein inhibition was calculated using the following formula: Percentage of violacein inhibition $=\left(\right.$ control $\mathrm{OD}_{585 \mathrm{~nm}}-$ test $\mathrm{OD}_{585 \mathrm{~nm}} /$ control $\left.\mathrm{OD}_{585 \mathrm{~nm}}\right) \times 100 .^{18}$

\section{2,2-diphenyl-1-picrylhydrazyl (DPPH) radical scavenging assay}

The DPPH free radical scavenging activity of the extract was determined in a sterile 96 -well plate. ${ }^{19}$ The DPPH $(0.02 \mathrm{mg} / \mathrm{ml})$ was mixed $(1: 1 \mathrm{v} / \mathrm{v})$ with different concentrations of the extract. Each mixture was made to stand for 30 minutes in darkness at room temperature $\left(25^{\circ} \mathrm{C}\right)$ and the absorbance was read at $517 \mathrm{~nm}$ using a microplate reader. The extract without DPPH served as blank while ascorbic acid (AA) and butylated hydroxyl anisole (BHA) was used as the positive controls. The percent inhibition of ABTS radical was calculated using the following formula: \%DPPH scavenging activity $=[\mathrm{Ao}-\mathrm{A} 1 / \mathrm{Ao}] \times 100$ where, $\mathrm{A} 1$ and Ao represent the absorbance recorded at $517 \mathrm{~nm}$ for the control and the test, respectively. The median inhibitory concentration $\left(\mathrm{IC}_{50}\right.$ ) of the extract against $\mathrm{DPPH}$ was calculated graphically.

\section{2, 2'-azino-bis-3-ethylbenzothiazoline-6-sulfonic acid (ABTS) radical scavenging assay}

The ABTS free radical scavenging activity of the extract was investigated using the serial dilution method. ${ }^{20}$ ABTS solution $(0.003 \mathrm{~g} / \mathrm{ml})$ was mixed $(1: 1 \mathrm{v} / \mathrm{v})$ with different concentrations of the extract. The mixtures were made to stand for 15 minutes at $25^{\circ} \mathrm{C}$ and the absorbance was read at $734 \mathrm{~nm}$ using a microplate reader. The extract without ABTS solution served as blank. Ascorbic acid (AA) and butylated hydroxyl anisole (BHA) were used as positive controls. The percent inhibition of ABTS radical was calculated by the following formula: \%ABTS scavenging activity $=[\mathrm{Ao}-\mathrm{A} 1 / \mathrm{Ao}] \times 100$ where, $\mathrm{A} 1$ and Ao equal the absorbance recorded at $734 \mathrm{~nm}$ of the control and the test, respectively. The median inhibitory concentration $\left(\mathrm{IC}_{50}\right)$ of the extract against ABTS was calculated graphically. 


\section{Cytotoxicity assay of the extract}

The cytotoxicity of the extract against human hepatocellular carcinoma (HepG2) cells was investigated using the methylthiazol tetrazolium (MTT) assay. HepG2 were grown to confluency in $25 \mathrm{~cm}^{3}$ flasks using complete culture medium (CCM: EMEM, 10\% foetal calf serum, $1 \%$ L-glutamine, $1 \%$ Penstrep-fungizone). Confluent cells were trypsinized and seeded into a 96-well plate in triplicate for treatment. Cells were incubated at $37^{\circ} \mathrm{C}$ for 24 hours to adhere and adapt. Thereafter, the CCM was removed and treated with different concentrations of the extract. After 24 hours, the treated medium was removed. A hundred microliters of fresh CCM and $20 \mu \mathrm{l}$ of MTT reagent $(5 \mathrm{mg} / \mathrm{ml}$ in PBS) were added into the wells and incubated at $37{ }^{\circ} \mathrm{C}$ for 4 hours. Tetrozolium-based columetric (MTT) solution was then aspirated from all wells and the formazan crystals were solubilized in $100 \mu \mathrm{L}$ of DMSO. The MTT reduction was obtained by measuring the optical density (OD) of the samples at 570 / $690 \mathrm{~nm}$ using the BioTek $\mu$ Quant microplate reader (USA). The cell viability percentage was measured by using the formula: Cell viability $(\%)=(\mathrm{OD}$ treated cells / OD untreated cells $\times 100$. The $\mathrm{IC}_{50}$ was calculated from the GraphPad Prism (V5) using linear regression analysis. ${ }^{21}$

\section{Software and statistical analysis}

All the experimentations were done in triplicates and the data were subjected to a one-way analysis of variance using Graph Pad Prism ${ }^{\mathrm{TM}}$ 6.1. Arrow bars represented the standard deviation and values with different alphabets represent the significant difference $(p<0.05)$.

\section{RESULTS AND DISCUSSION}

\section{Biosynthetic gene clusters}

Secondary metabolites from bacteria constitute an important source of effective pharmacological agents. These metabolites are biomolecules that are encoded by different gene clusters. The well-known family clusters are $\mathrm{N}_{-}-$-acetylglutaminylglutamine1-amide (NAGGN), nonribosomal peptide synthase (NRPS), and polyketide synthase (PKS). ${ }^{22}$ The potential production of secondary metabolites by $P$. aeruginosa CP043328.1 was predicted by antiSMASH version 5 . There are 12 biosynthetic gene clusters observed (Table 1). The bacterium was predicted to certainly produce L-2-amino-4-methoxy-trans-3-butenoic acid and pyocyanine as the nonribosomal peptide synthetase (NRPS) and phenazine clusters. showed $100 \%$ similarity to the gene clusters involved in the production of this metabolites, respectively. ${ }^{23}$ Apart from these two clusters, the percentage similarity to most known clusters are very low $(\leq 50 \%)$. This implies that the metabolites produced by different gene clusters cannot be accurately predicted. In general, the different biosynthetic gene cluster advocated for the ability of the bacterium to produce diverse types of secondary metabolites of pharmacological importance.

\section{Metabolites extraction}

Ethyl acetate solvent was used to extract the secondary metabolites and it gave a yield of $0.6 \mathrm{~g} / 500 \mathrm{ml}$. Ethyl acetate is an effective solvent for the extraction of active metabolites from microorganisms as it can dissolve both polar and non- polar active compounds. ${ }^{24}$

\section{Volatile chemical constituents}

GC-MC chromatogram profile of the extract showed different volatile constituents. A total of 15 volatile compounds were identified (Table 2 and Figure 1). Two compounds namely diisooctyl phthalate and 9-octadecenamide were found to be major in this fraction with $50.51 \%$ and $10.44 \%$ peak area respectively. Many other constituents were also identified such as: [1,2,4] oxadiazole, 5-benzyl-3- (thiophen-2-yl) (5.70\%), 2-dodecenoic acid (5.51\%), trans-2-decenoic acid (4.57\%), xanthoxylin (3.74\%), L-proline, N-valeryl-, undecyl ester $(2.86 \%)$, L-proline, $\mathrm{N}$-valeryl-, tetradecyl ester (2.61\%), pyrrolo[1,2-a]pyrazine1,4-dione, hexahydro-3-(2-methylpropyl) (2.37\%), pentadecanoic acid (2.13\%), cis-9-octadecenoic acid (2.13\%), cyclohexanone, 4-methyl, O-methyloxime (2.04\%), 3-nonynoic acid (1.88\%), benzonitrile, 2-(2-pyridinyl) (1.88\%) and ergotaman-3',6',18-trione,9,10-dihydro12'-hydroxy-2'-methyl-5'-(phenylmethyl) (1.68\%). Most of the identified compounds have been reported to possess interesting biological activities; xanthoxylin has antimicrobial activity, ${ }^{25}$ trans-2Decenoic acid has anti-tumor and antibiotic activities ${ }^{26}$ and dodecenoic acid possesses antioxidant, anti-inflammatory and antimicrobial properties. ${ }^{27}$ 3-Nonynoic, pyrrolo[1,2-a]pyrazine-1,4-dione, hexahydro-3-(2-methylpropyl), pentadecanoic acid and diisooctyl phthalate have antimicrobial activities ${ }^{28-31}$. cis-9-Octadecenoic acid has been reported to possess antioxidant properties. ${ }^{32}$ Ergotaman-3',6',18 trione, 9,10 dihydro-12'-hydroxy-2'-methyl-5'(phenylmethyl)- is a new chemical and its biological activities are unknown. ${ }^{33}$ 9-Octadecenamide has antioxidant and anticancer properties ${ }^{32}$ while $[1,2,4]$ oxadiazole, 5-benzyl-(thiophen-2-yl) has anti-inflammatory, ${ }^{33,34}$ antibiotic $^{35,36}$ and anticancer activities. ${ }^{37,38}$ Thus, the extract has potential to serve as a source of pharmacologically active compounds.

\section{Anti-quorum sensing activity}

The quorum quenching mechanism seems to be a promising alternative to classical antimicrobial effects and a solution to the constant increase in multidrug resistance among pathogens. Violacein inhibition was evaluated by using C. violaceum ATCC 12472 as a bio-indicator against

Table 1:The biosynthetic gene clusters are associated with secondary metabolites production by $P$. aeruginosa CP043328.1. The standard abbreviations signifying the type of clusters as indicated in anti-SMASH are used.

\begin{tabular}{|c|c|c|c|}
\hline Number of clusters & Types of Clusters & Most similar known Clusters & Similarity (\%) \\
\hline 1 & NRPS, phenazine & Marinophenazine A / phenaziterpene A & 26 \\
\hline 2 & NRPS-like & & \\
\hline 3 & Hserlactone & & \\
\hline 4 & NAGGN & & \\
\hline 5 & NRPS & & \\
\hline 6 & Bacteriocin & & \\
\hline 7 & NRPS & Pyoverdin & 24 \\
\hline 8 & NRPS & L-2-amino-4-methoxy-trans-3-butenoic acid & 100 \\
\hline 9 & Thipeptide & oxalomycin B & 6 \\
\hline 10 & Phenazine & Pyocyanine & 100 \\
\hline 11 & Hserlactone & & \\
\hline 12 & NRPS-like, betalactone & Pyoverdin & 2 \\
\hline
\end{tabular}


Table 2: Volatile constituents of $P$. aeruginosa CP043328.1 extract.

\begin{tabular}{clc}
\hline Number of compounds & Compounds & Area (\%) \\
\hline 1 & Xanthoxylin & 3.74 \\
2 & Cyclohexanone, 4-methyl-, O-methyloxime & 2.04 \\
3 & trans-2-Decenoic acid & 4.57 \\
4 & 3-Nonynoic acid & 1.88 \\
5 & 2-Dodecenoic acid & 5.51 \\
6 & Pyrrolo[1,2-a]pyrazine-1,4-dione,hexahydro-3-(2-methylpropyl) & 2.37 \\
7 & L-Proline, N-valeryl-, tetradecyl ester & 2.61 \\
8 & L-Proline, N-valeryl-, undecyl ester & 2.82 \\
9 & Pentadecanoic acid & 2.13 \\
10 & cis-9-Octadecenoic acid & 2.13 \\
11 & Ergotaman-3',6',18-trione,9,10-dihydro-12'-hydroxy-2'-methyl-5'-(phenylmethyl)- & 1.68 \\
12 & 9-Octadecenamide & 10.44 \\
13 & [1,2,4]Oxadiazole, 5-benzyl-3-(thiophen-2-yl) & 5.70 \\
14 & Benzonitrile, 2-(2-pyridinyl)- & 1.88 \\
& Diisooctyl phthalate & 50.51
\end{tabular}

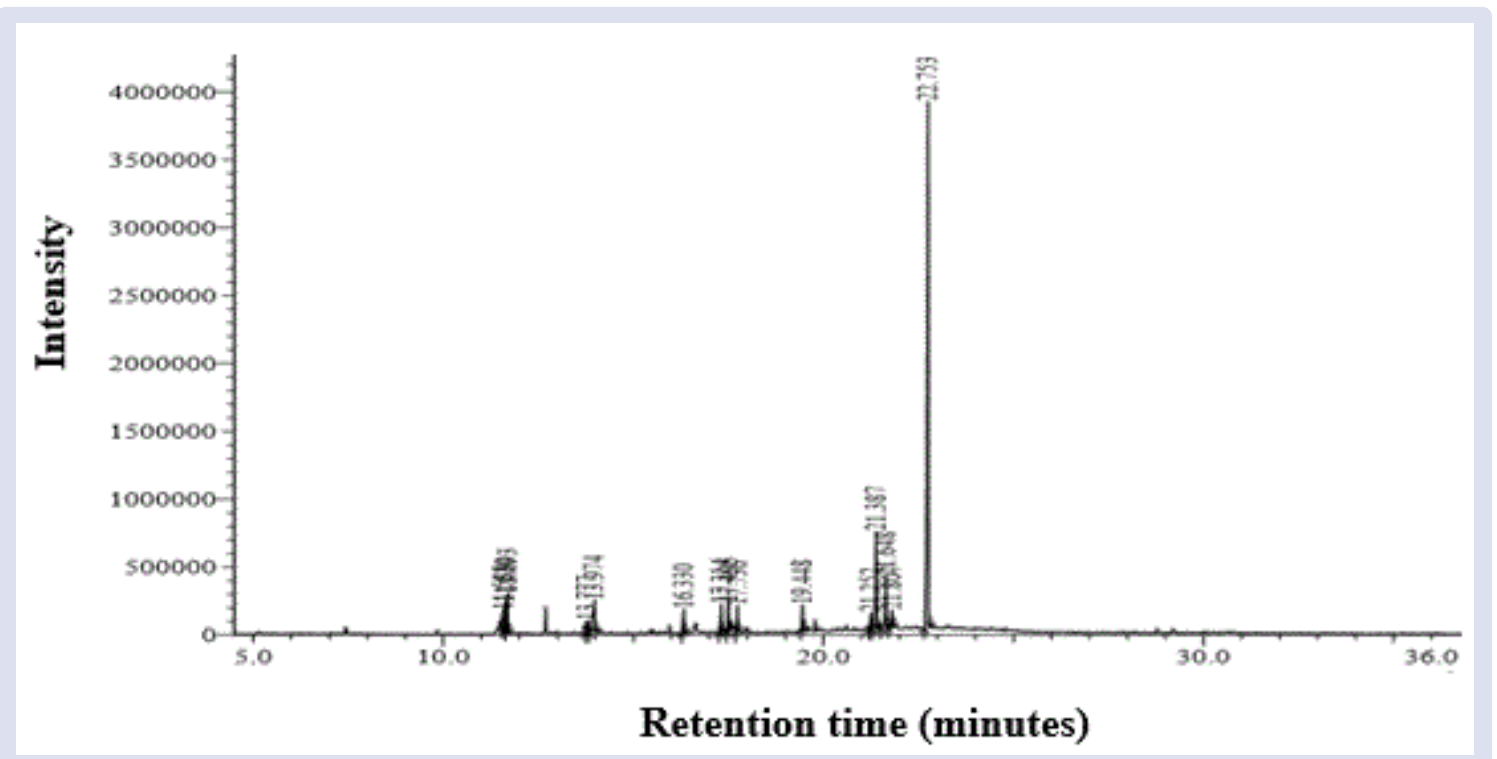

Figure 1: A GC-MS chromatogram peak profile of $P$. aeruginosa CP043328.1 extract.

different concentrations of the extract. The inhibition of the violacein production by the extract is shown in Figure 2. Violacein inhibition increased with an increase in the concentration of the extract up to $88 \%$ at $3.21 \mathrm{mg} / \mathrm{ml}$. w. An extract is regarded as highly active when it is $\geq 90 \%$, moderate between $40-89 \%$, and inactive when it is $<40 \%{ }^{39}$ This implied that the extract has moderate activity and could be used as an anti-quorum agent. Different mechanisms have been reported to elucidate the interference of quorum sensing by natural products. Some of the mechanisms are inhibition of signaling molecules, biosynthesis of acyl-homoserine lactones (AHL) signaling reception, and biodegradation of quorum molecules. ${ }^{40}$ It was therefore assumed that the extract exerted one or all of these mechanisms of action. Moreover, the results showed that the extract inhibits quorum sensing without interfering with the growth of the bacterium. It was concluded that the negative effect on violacein production was not caused by the inhibition of C. violaceum growth but rather by disruption of the signaling system. ${ }^{41}$ This is important because when growth is not affected, there is no selective pressure for the development of resistant bacteria. ${ }^{38}$ Thus, this study introduces not only a novel antibiotic but also a potential new therapeutic direction for the treatment of bacterial infections.

\section{Antioxidant activity}

Antioxidants have a critical role in negating disease progression caused by excess free radicals. ${ }^{42}$ The antioxidant activity of the extract was evaluated by free radical DPPH and ABTS methods and the results are displayed in Figure 3. The extract exhibited maximum DPPH scavenging activity of $63 \%$ at $1.0 \mathrm{mg} / \mathrm{ml}$ and displayed the $\mathrm{IC}_{50}$ value of $0.650 \mathrm{mg} / \mathrm{ml}$, which was higher than that of ascorbic acid $(0.200 \mathrm{mg} /$ $\mathrm{ml})$ and BHA $(0.188 \mathrm{mg} / \mathrm{ml})$. It also demonstrated a maximum ABTS scavenging activity of $91 \%$ at $0.5 \mathrm{mg} / \mathrm{ml}$ with an $\mathrm{IC}_{50}$ value of $0.150 \mathrm{mg} /$ $\mathrm{mL}$ (Figure 3). Its $\mathrm{IC}_{50}$ value was lower than of ascorbic acid $(0.258$ $\mathrm{mg} / \mathrm{ml})$ and BHA $(0.300 \mathrm{mg} / \mathrm{ml})$. The results imply that the extract has stronger activity against ABTS than the controls but poor action against DPPH in comparison to the controls. Antioxidant compounds are said to be very strong if they have $\mathrm{IC}_{50}$ values of less than 0.05 $\mathrm{mg} / \mathrm{ml}$, strong for $\mathrm{IC}_{50}$ between $0.05-0.10 \mathrm{mg} / \mathrm{ml}$, moderate for $\mathrm{IC}_{50}$ between $0.10-0.15 \mathrm{mg} / \mathrm{ml}$ and weak if $\mathrm{IC}_{50}$ is greater than $0.150 \mathrm{mg} / \mathrm{ml}$. ${ }^{38}$ Thus, the extract revealed moderate activity against ABTS radical and poor activity against DPPH radical. The observed antioxidant activity was attributed to the different identified antioxidant metabolites acting 
synergistically. Moreover, the extract has the potential to serve as a source of antioxidant compounds, especially against ABTS radicals. The evaluation of antioxidant activity was of utmost importance in this study as few studies are reporting on the antioxidant activity of extracts or compounds from endophytic bacteria.

\section{Cytotoxicity}

Toxicity is the measure of the adverse effects of compounds on the cells or organs in biological systems; it is a crucial parameter to evaluate during drug discovery and development processes. Toxicity issues accounted for approximately $54 \%$ of failures in the preclinical stages in drug discovery and development. ${ }^{43}$ The cytotoxicity effect of the $P$. aeruginosa CP043328.1's extract on healthy HepG2 cells was evaluated by MTT assay and the results are displayed in Figure 4. After treatment with the extract, there was an initial increase in cell viability, indicative of metabolism stimulation. The highest viability of $109 \%$ was observed at $125 \mu \mathrm{g} / \mathrm{ml}$ and fluctuated at $\pm 100 \%$ between $500-1500 \mu \mathrm{g} / \mathrm{ml}$. The lowest viability was observed at $1000 \mu \mathrm{g} / \mathrm{ml}( \pm 1 \%)$, indicative of the

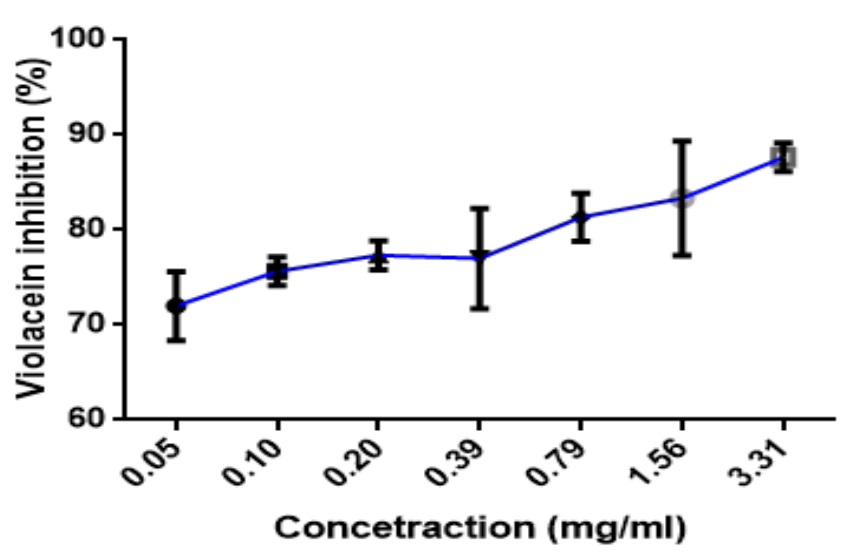

Figure 2: Violacein inhibition of $P$. aeruginosa CP043328.1 extract.
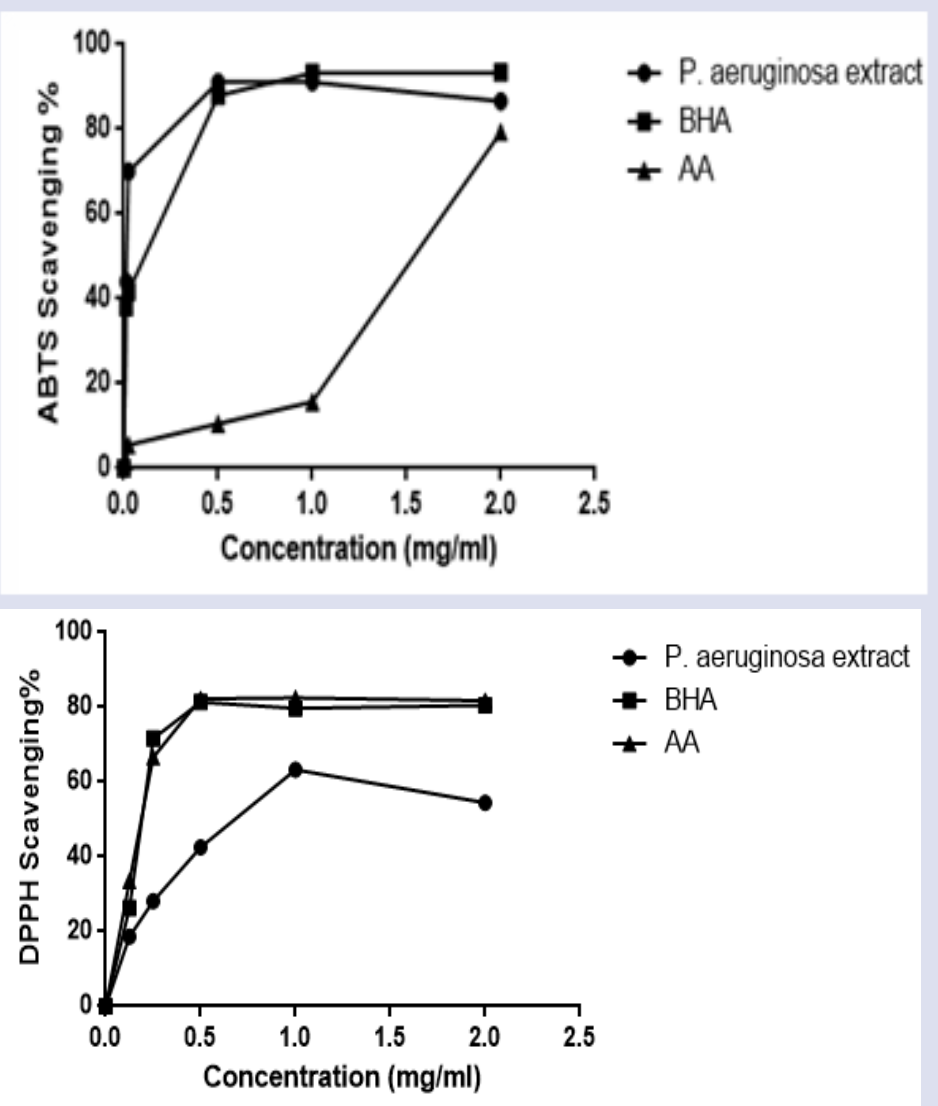

Figure 3: ABTS scavenging activity of the extract, BHA, and AA (left) and DPPH scavenging activity of the extract, $\mathrm{BHA}$, and $\mathrm{AA}$ (right). P. aeruginosa denotes extract, BHA denotes butylated hydroxyl anisole and AA denotes ascorbic acid. 


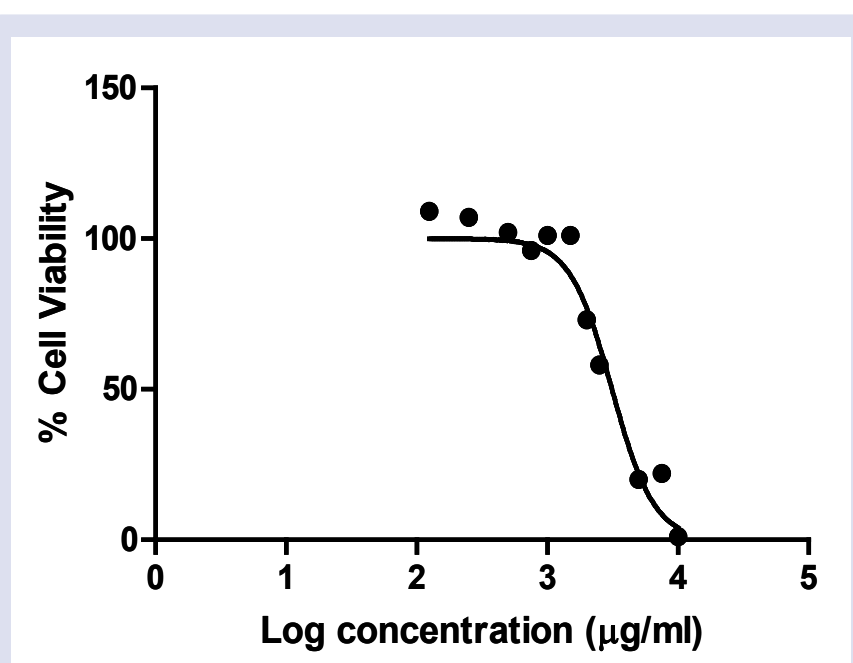

Figure 4: Cytotoxic activity of the extract against HepG2 liver carcinoma cells at different concentrations.

cytotoxic effect of the extract against HepG2 cells. The concentration that was found to inhibit $50 \%$ of the metabolic activity of the cells was $3123 \mu \mathrm{g} / \mathrm{ml}$. According to our observation, the extract is safe for use up to $2000 \mu \mathrm{g} / \mathrm{ml}$. However, above this concentration $(2000 \mu \mathrm{g} / \mathrm{ml})$, the extract is capable of inhibiting mitochondrial activity and ATP production, suggesting that the concentrations (greater than $2000 \mu \mathrm{g} /$ $\mathrm{ml}$ ) can negatively affect cell function. Moreover, it was concluded that the extract could be safe for use as an antioxidant source since its cytotoxic $\mathrm{IC}_{50}$ value is higher than the concentration range regarded as significant for antioxidant scavenging agents.

\section{CONCLUSION}

P. aeruginosa CP043328.1 has 12 gene clusters that encode for the production of secondary metabolites. Fifteen chemical compounds were identified using GC-MS analysis. The ethyl acetate extract demonstrated the significant antioxidant and anti-quorum sensing activities. Thus, Pseudomonas aeruginosa CP043328.1 shows a potential niche in industries for the production of pharmacologically effective and valuable secondary metabolites. For further studies, in vivo assays are recommended.

\section{ACKNOWLEDGMENTS}

The authors acknowledge the Department of Biochemistry and Microbiology, University of Zululand and National Research Foundation of South Africa (Grant number: HBG 181011371909) for providing facilities and funds to conduct this research.

\section{CONFLICTS OF INTEREST}

The authors declare no conflicts of interest.

\section{ABBREVIATIONS}

ATCC: American Type Culture Collection; Anti-Smash: Antibiotic and Secondary metabolite Analysis Shell; DMSO: dimethyl sulfoxide; DPPH: 2.2-diphenyl-1-picrylhydrazyl radical scavenging assay; ABTS: 2, 2'-azino-bis-3-ethylbenzothiazoline-6-sulfonic acid radical scavenging assay; MTT: Methylthiazol tetrazolium; HepG2: human hepatocellular carcinoma; rpm: revolution per minute; $\mathrm{IC}_{50}:$ median inhibitory concentration; $\mu \mathrm{g} / \mathrm{mL}$ : microgram/milliliter; g: gram; $\mathrm{mL}$ : millimeter; ${ }^{\circ} \mathrm{C}$ : degree Celsius; $\mu \mathrm{L}$ : microliter; \%: percent; AA: ascorbic acid; BHA: butylated hydroxyl anisole; EF: extract; GC-MS: gas chromatography-mass spectrometry; GC: gas chromatography; MS: mass spectrometry; MIC: minimum inhibitory concentration; MBC: minimum bactericidal concentration; QS: quorum sensing; v: volume; A. cordifolia: Anredera cordifolia; C. violeceum: Chromobacterium violeceum; P. aeruginosa: Pseudomonas aeruginosa.

\section{REFERENCES}

1. WHO G. Who methods and data sources for global burden of disease estimates 2000-2011. Geneva: Department of Health Statistics and Information Systems. 2013 http://www.who.int/gho/mortality_ burden_disease/en/index.html.

2. Walsh C. Where will new antibiotics come from? Nature Reviews Microbiology. 2003;1(1):65-70.

3. Westh H, Zinn CS, RosdahIVT, SS Group. An international multicenter study of antimicrobial consumption and resistance in Staphylococcus aureus isolates from 15 hospitals in 4.14 countries. Microbial Drug Resistance. 2004; 10(2):169-76.

4. Janso JE, Carter GT. Biosynthetic potential of phylogenetically unique endophytic actinomycetes from tropical plants. Applied and Environmental Microbiology. 2010;76(13):4377-86.

5. Valko M, Leibfritz D, Moncol J, Cronin MT, Mazur M, Telser J. Free radicals and antioxidants in normal physiological functions and human disease. The International Journal of Biochemistry \& Cell biology. 2007;39(1):44-84.

6. Janardhan A, Kumar AP, Viswanath B, Saigopal D, Narasimha G. Production of bioactive compounds by actinomycetes and their antioxidant properties. Biotechnology Research International, 2014.

7. Lee S, Park SJ, Kim JH, Min BD, Chung MH, Park S. Characterization of culturable bacteria in the atmospheric environment in incheon, Korea. Journal of Environmental Health Sciences. 2016;42(2):126-32

8. Misra N, Gupta G and Jha PN. Assessment of mineral phosphatesolubilizing properties and molecular characterization of zinc-tolerant bacteria. Journal of Basic Microbiology. 2012;52(5).

9. Devi KA, Pandey G, Rawat A, Sharma GD and Pandey P. The endophytic symbiont-Pseudomonas aeruginosa stimulates the antioxidant activity and growth of achyranthes aspera I. Frontiers in Microbiology. 2017;8:1897.

10. Bilal S, Ali L, Khan AL, Shahzad R, Asaf S, Imran M, et al. Endophytic fungus Paecilomyces formosus $\mathrm{Ihl} 10$ produces sester-terpenoid yw3548 and cyclic peptide that inhibit urease and $\alpha$-glucosidase enzyme activities. Archives of Microbiology. 2018;200(10):1493-502:

11. Butler MS, Blaskovich MA, Cooper MA. Antibiotics in the clinical pipeline in 2013. The Journal of Antibiotics. 2013;66(10):571-91.

12. Onbasli D, Aslim B. Determination of antimicrobial activity and production of some metabolites by Pseudomonas aeruginosa b1 and b2 in sugar beet molasses. African Journal of Biotechnology. 2008;7(24).

13. Shimazaki M, Hasegawa J, kan K, Nomura K, Nose $Y$, Kondo $H$, Ohashi T, Watanabe K. Synthesis of captopril starting from an optically active $\beta$-hydroxy acid. Chemical and Pharmaceutical Bulletin, 1982;30(9):3139-46:

14. Allouche N, Damak M, Ellouz R, Sayadi S. Use of whole cells of Pseudomonas aeruginosa for synthesis of the antioxidant hydroxytyrosol via conversion of tyrosol. Applied and Environmental Microbiology. 2004;70(4):2105-9.

15. Medema MH, Blin K, Cimermancic $P$, de Jager $V$, Zakrzewski $P$ Fischbach MA, Weber T, Takano E, Breitling R. Antismash: Rapid identification, annotation and analysis of secondary metabolite biosynthesis gene clusters in bacterial and fungal genome sequences. Nucleic Acids Research, 2011;39(suppl_2):W339-W346

16. Kim HY, Choi G, Lee H, Lee SW, Lim H, Jang K, Son S, Lee S, Cho K, Sung N. Some fungal endophytes from vegetable crops and their anti-oomycete activities against tomato late blight. Letters in Applied Microbiology. 2007;44(3):332-7.

17. Mboyazi SN, Nqotheni MI, Maliehe TS and Shandu JS. In vitro antibacterial and in silico toxicity properties of phytocompounds from Ricinus communis leaf extract. Pharmacognosy Journal. 2020;12(5):977-83. 
18. Chenia, HY. Anti-quorum sensing potential of crude Kigelia africana fruit extracts. Sensors. 2013;13(3):2802-17.

19. Brand-Williams, W, Cuvelier ME, Berset C. Use of a free radical method to evaluate antioxidant activity. LWT-Food science and Technology. 1995;28(1):25-30.

20. Re R, Pellegrini N, Proteggente A, Pannala A, Yang M, Rice-Evans C. Antioxidant activity applying an improved ABTS radical cation decolorization assay. Free Radical Biology and Medicine. 1999;26(910):1231-7.

21. Mosmann T. Rapid colorimetric assay for cellular growth and survival: Application to proliferation and cytotoxicity assays. Journal of Immunological Methods. 1983;65(1-2):55-63.

22. Chavali AK, Rhee SY. Bioinformatics tools for the identification of gene clusters that biosynthesize specialized metabolites. Briefings in Bioinformatics. 2018;19(5):1022-34.

23. Khumalo MJ, Nzuza N, PadayacheeT, Chen W, Yu JH, Nelson DR, Syed K. Comprehensive analyses of cytochrome P450 monooxygenases and secondary metabolite biosynthetic gene clusters in cyanobacteria. International Journal of Molecular Sciences. 2020;21(2):656.

24. Ramachandran G, Rajivgandhi G, Maruthupandy M, Manoharan $\mathrm{N}$. Extraction and partial purification of secondary metabolites from endophytic actinomycetes of marine green algae Caulerpa racemosa against multi drug resistant uropathogens. Biocatalysis and Agricultural Biotechnology. 2019;17:750-7.

25. dos Reis CM, da Rosa BV, da Rosa GP, do Carmo G, Morandini $\mathrm{LMB}$, Ugalde GA, et al. Antifungal and antibacterial activity of extracts produced from Diaporthe schini. Journal of Biotechnology. 2019;294:30-7.

26. Sugiyama T, Takahashi K, H. Mori H. Royal jelly acid, 10-hydroxy-trans2-decenoic acid, as a modulator of the innate immune responses. Endocrine. Metabolic \& Immune Disorders-Drug Targets (Formerly Current Drug Targets-Immune, Endocrine \& Metabolic Disorders). 2012;12(4):368-76.

27. Özçelik B, Aslan M, Orhan I, Karaoglu T. Antibacterial, antifungal, and antiviral activities of the lipophylic extracts of Pistacia vera. Microbiological Research. 2005;160(2):159-64.

28. Hussein AO, Mohammed GJ, Hadi MY, Hameed IH, 2016. Phytochemical screening of methanolic dried galls extract of Quercus infectoria using gas chromatography-mass spectrometry (GC-MS) and Fourier transform-infrared (FT-IR). Journal of Pharmacognosy and Phytotherapy. 2016;8(3):49-59.

29. Dash S., Jin C, Lee OO, Xu Y, Qian PY. Antibacterial and antilarvalsettlement potential and metabolite profiles of novel spongeassociated marine bacteria. Journal of Industrial Microbiology \& Biotechnology. 2009;36(8):1047-56.

30. Belakhdar G, Benjouad A, Abdennebi E. Determination of some bioactive chemical constituents from Thesium humile vahl. Journal of Materials and Environtal Sciennce, 2015;6(10):2778-83.
31. Altaee N, Kadhim MJ, Hameed IH. Detection of volatile compounds produced by Pseudomonas aeruginosa isolated from UTI patients by gas chromatography-mass spectrometry. International Journal of Current Pharmaceutical Review and Research. 2007(6):8-24.

32. Abou-Elela GM, Abd-Elnaby H, Ibrahim HA, Okbah M. Marine natural products and their potential applications as anti-infective agents. World Applied Science Journal. 2009;7(7):872-80.

33. Farooqui $M$, Bora $R$, Patil C. Synthesis, analgesic and antiinflammatory activities of novel 3-(4-acetamido-benzyl)-5substituted-1, 2, 4-oxadiazoles. European Journal of Medicinal Chemistry. 2009;44(2):794-9.

34. Gobec M, Tomašič T, Markovič T, Mlinarič-Raščan I, Dolenc MS, Jakopin Z. Antioxidant and anti-inflammatory properties of 1,2 , 4-oxadiazole analogs of resveratrol. Chemico-biological Interactions. 2015;240:200-7.

35. Spink E, Ding D, Peng Z, Boudreau MA, Leemans E, Lastochkin $\mathrm{E}$, et al. Structure-activity relationship for the oxadiazole class of antibiotics. Journal of Medicinal Chemistry. 2015;58(3):1380-9.

36. Leemans E, Mahasenan KV, Kumarasiri M, Spink E, Ding D, O'Daniel $\mathrm{PI}$, et al. Three-dimensional QSAR analysis and design of new 1 , 2, 4-oxadiazole antibacterials. Bioorganic \& Medicinal Chemistry Letters. 2016;26(3):1011-5.

37. Kumar D, Patel G, Chavers AK, Chang KH, Shah K. Synthesis of nove $1,2,4$-oxadiazoles and analogues as potential anticancer agents. European Journal of Medicinal Chemistry. 2011;46(7):3085-92.

38. Moniot S, Forgione M, Lucidi A, Hailu GS, Nebbioso A, Carafa V, et al Development of 1, 2, 4-oxadiazoles as potent and selective inhibitors of the human deacetylase sirtuin 2: Structure-activity relationship, $x$-ray crystal structure, and anticancer activity. Journal of Medicinal Chemistry. 2017; 60(6):2344-60.

39. Tsilo PH, Maliehe TS, Shandu JS, Khan R. Chemical composition and some biological activities of the methanolic Encephalartos ferox fruit extract. Pharmacognosy Journal. 2020;12(5):1190-7.

40. Rasmussen TB, Givskov M. Quorum-sensing inhibitors as antipathogenic drugs. International Journal of Medical Microbiology. 2006;296(2-3):149-61.

41. Kociolek MG. Quorum-sensing inhibitors and biofilms. Anti-Infective Agents in Medicinal Chemistry (Formerly Current Medicinal Chemistry-Anti-Infective Agents). 2009;8(4):315-26.

42. Molyneux $P$. The use of the stable free radical diphenylpicrylhydrazyl (DPPH) for estimating antioxidant activity. Songklanakarin Journal of Science and Technology. 2004;26(2):211-9.

43. Paul SM, Mytelka DS, Dunwiddie CT, Persinger CC, Munos BH, Lindborg SR, Schacht AL. How to improve R\&D productivity: The pharmaceutical industry's grand challenge. Nature reviews Drug discovery. 2010;9(3):203-14. 


\section{GRAPHICAL ABSTRACT}

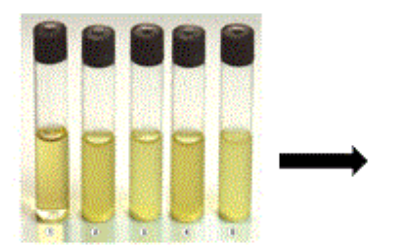

Pseudomonas aeruginosa CP043328.1

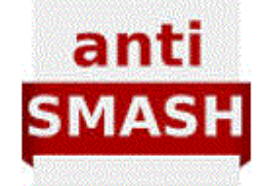

Biosynthetic gene clusters
Solvent extraction

Ethyl acetate

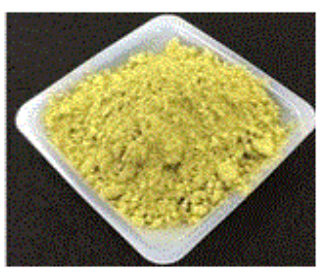

Extract

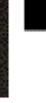
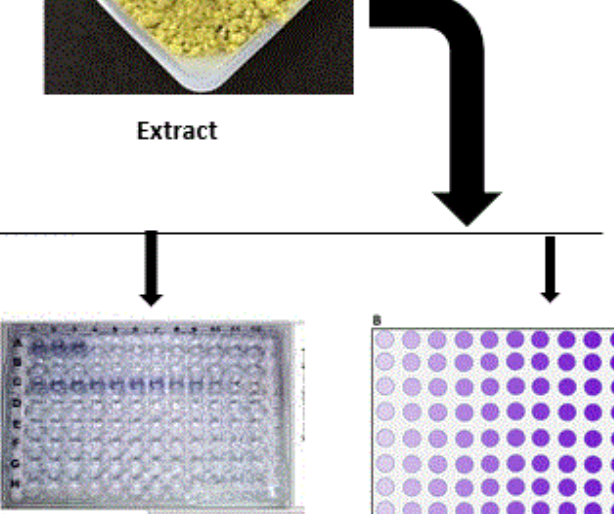

Antioxidant activity sensing activity

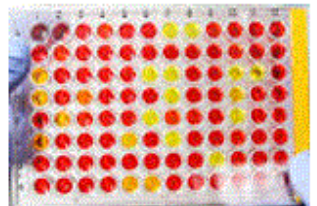

GC-MS

\section{ABOUT AUTHORS}

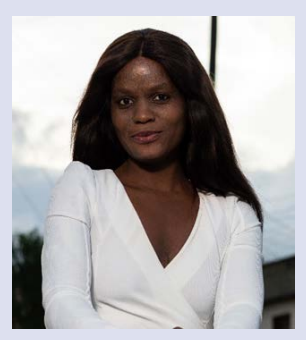

Ms Londeka Sibusisiwe Ngidi holds a BSc. Degree in Biochemistry and Microbiology and a BScHonours in Microbiology. She is currently doing her $2^{\text {nd }}$ year MSc degree in Microbiology from the same institution. Her research project is on screening of endophytic bacteria from Anredera cordifolia leaves for secondary metabolites production and their biological activities. She has published some of her work in accredited academic journals.

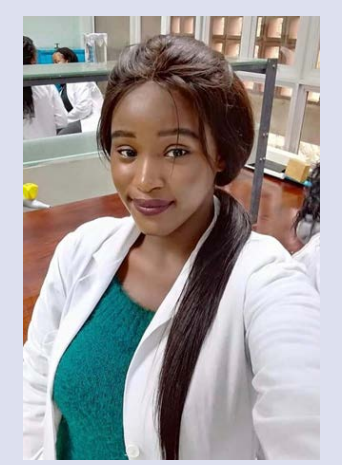

Ms Celiwe Innocentia Nxumalo obtained her BSc-Honours degree in Microbiology at the University of Zululand. Her focus was on biological activities of secondary metabolites from endophytic bacteria. She is pursuing her $1^{\text {st }}$ year MSc. degree in Microbiology at the University of Pretoria. Her research project is on assessing the functions of Phytophthora parasitica RXLR effectors in Nicotiana benthamiana immunity. She has publications in different accredited academic journals.

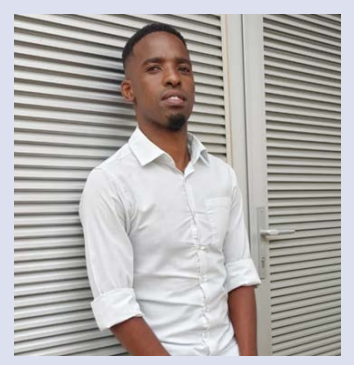

Dr. TS Maliehe holds a BSc degree in Biotechnology and BSc-Honours, MSc and PhD degrees in Microbiology from the University of Zululand. He is a postdoctoral fellow in the same institution. His research expertise falls within the Environmental Microbiology with emphasis on wastewater treatment using microbial bioflocculants. He is an expert in bioactive compounds of health importance from microbial origin (endophytes) and plants. He is also well informed in Bioinformatics. He has collaborated with a large number of researchers and academics and published his work in highly rated accredited journals. 


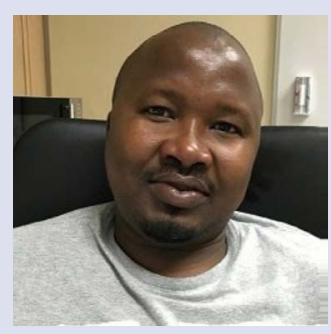

\section{Mr. Jabulani Siyabonga Shandu}

Position: Lecturer

Phone: (035)902-6201

Email: Shanduj@unizulu.ac.za

Building \&Room: Room, Sc.255, 1ST Floor, Natural Science Building

Biography:

Mr J.S. Shandu is a lecturer in the field of Microbiology at the University of Zululand at kwaDlangezwa campus. He holds a MSc. degree in Microbiology. His research interests are in phytomedicine and aquatic microbiology.

Qualifications:

BSc, BSc (Hons.), MSc. (Microbiology). University of Zululand.

Research interests:

Medicinal plant properties and Water quality monitoring

Professional membership:

- SASM-KZN

Research Databases / Publications:

Has published on several academic journals since 2008, particularly in phytomedicine.

Cite this article: Ngidi LS, Nxumalo Cl, Shandu JS, MalieheTS, Rene K. Antioxidant, Anti-quorum Sensing and Cytotoxic Properties of the Endophytic Pseudomonas Aeruginosa CP043328.1 's ExtractPharmacog J. 2021;13(2): 332-40. 